\title{
Wariantowanie skalą przedsięwzięcia. Glosa do wyroku Naczelnego Sądu Administracyjnego z dnia 23 stycznia 2019 r., II OSK 3147/18
}

\author{
Alternatives of the scale of the project. Gloss on Supreme Administrative Court \\ judgment of 23 January 2019, II OSK 3147/18 \\ Изменение масштаба проекта. Комментарий к постановлению Высшего \\ Административного Суда от 23 января 2019 года, II OSK 3147/18
}

\author{
JACEK KRYSTEK \\ Dr inż., Politechnika Łódzka \\ e-mail: jacek.krystek@p.lodz.pl, https://orcid.org/0000-0002-7251-9675
}

\begin{abstract}
Streszczenie: Glosa odnosi się do wyroku Naczelnego Sądu Administracyjnego z dnia 23 stycznia 2019 r., II OSK 3147/18, w którym stwierdzono, że zmiana mocy farmy wiatrowej nie jest wariantem alternatywnym, lecz innym rodzajem przedsięwzięcia. Zastosowany przez sąd sposób wnioskowania został poddany wyczerpującej analizie i krytyce. Ustawa z dnia 3 października 2008 r. o udostępnianiu informacji o środowisku i jego ochronie, udziale społeczeństwa w ochronie środowiska oraz o ocenach oddziaływania na środowisko nie wprowadza żadnych wymogów formalnych, jakie w czasie oceny oddziaływania na środowisko muszą spełniać analizowane warianty, za wyjątkiem alternatywności w stosunku do wariantu proponowanego przez wnioskodawcę.
\end{abstract}

Słowa kluczowe: ocena oddziaływania na środowisko, warianty przedsięwzięcia, raport oceny oddziaływania na środowisko, skala przedsięwzięcia

Summary: The gloss is concerned with the judgment of the Polish Supreme Administrative Court of 23 January 2019, II OSK $3147 / 18$, which states that a change in the wind farm capacity is not an alternative option but a different type of enterprise. The method of inference as applied by the Court was thoroughly analyzed and criticized. The Act on the provision of information on the environment and its protection, public participation in environmental protection, and on environmental impact assessments does not introduce any formal requirements that must be met by the analyzed variants during the environmental impact assessment, except for the alternative to the variant proposed by the applicant.

Key words: environmental impact assessment, alternatives, environmental impact assessment report, scale of the project

Резюме: Комментарий касается постановления Высшего Административного Суда от 23 января 2019 года, II OSK 3147/18, в котором был сделан вывод, что изменение мощности ветропарка не является альтернативным вариантом, а другим видом проекта. Метод умозаключения, примененный судом, был всесторонне проанализирован и подвергнут критике. Закон от 3 октября 2008 года «О предоставлении информации об окружающей среде и ее охране, участии общественности в охране окружающей среды и оценке воздействия на окружающую среду» не вводит каких-либо формальных требований, которым должны соответствовать анализируемые варианты при проведении оценки их воздействия на окружающую среду, за исключением альтернативы по отношению к варианту, предложенному заявителем.

Ключевые слова: оценка воздействия на окружающую среду, варианты проектов, отчет об оценке воздействия на окружающую среду, масштаб проекта 


\section{Wstęp}

Ustawa o udostępnianiu informacji o środowisku i jego ochronie, udziale społeczeństwa w ochronie środowiska oraz o ocenach oddziaływania na środowisko nie wprowadza żadnych wymogów formalnych, jakie w czasie oceny oddziaływania na środowisko muszą spełniać analizowane warianty, za wyjątkiem alternatywności w stosunku do wariantu proponowanego przez wnioskodawcę.

Podczas oceny oddziaływania na środowisko planowanego przedsięwzięcia, zgodnie z ustawą z dnia 3 października 2008 r. o udostępnianiu informacji o środowisku i jego ochronie, udziale społeczeństwa w ochronie środowiska oraz o ocenach oddziaływania na środowisko ${ }^{1}$, należy dokonać analizy wariantów tego przedsięwzięcia. Glosowany wyrok ${ }^{2}$ zapadł w związku $\mathrm{z}$ analizą prawidłowości lokalizacji farmy wiatrowej podczas wydawania decyzji o środowiskowych uwarunkowaniach realizacji przedsięwzięcia.

\section{Stan faktyczny}

W stanie faktycznym, leżącym u podstaw komentowanego orzeczenia Naczelnego Sądu Administracyjnego, skarżący złożyli wniosek o stwierdzenie nieważności decyzji Wójta Gminy D. w sprawie środowiskowych uwarunkowań dla przedsięwzięcia polegającego na budowie i eksploatacji farmy wiatrowej. Samorządowe Kolegium Odwoławcze odmówiło stwierdzenia nieważności decyzji Wójta Gminy D. Skarżący, nie zgadzając się z decyzją Kolegium, złożyli wniosek o ponowne rozpatrzenie sprawy i wnieśli o jej załatwienie $z$ uwzględnieniem ich słusznego interesu, jako właścicieli działki zlokalizowanej w pobliżu planowanego przedsięwzięcia, oraz stwierdzenie nieważności decyzji Wójta Gminy D. Samorządowe Kolegium Odwoławcze utrzymało w mocy własną decyzję, nie znajdując przesłanek do uznania żądania skarżących. Następnie skarżący wnieśli do Wojewódzkiego Sądu Administracyjnego w Szczecinie wniosek o stwierdzenie nieważności decyzji Wójta Gminy D., ewentualnie o uchylenie decyzji Samorządowego Kolegium Odwoławczego i przekazanie sprawy temu organowi do ponownego rozpoznania. Na tym etapie postępowania sądowego wniosek o dopuszczenie do udziału w sprawie złożyły:

1 Ustawa z dnia 3 października 2008 r. o udostępnianiu informacji o środowisku i jego ochronie, udziale społeczeństwa w ochronie środowiska oraz o ocenach oddziaływania na środowisko, tekst jednolity: Dz. U. z 2021 r. poz. 247 z późn. zm.

2 LEX nr 2646242. 
Stowarzyszenie na Rzecz Mieszkańców Gminy D. i Stowarzyszenie Rozwoju Miejscowości B. Wojewódzki Sąd Administracyjny w Szczecinie dopuścił Stowarzyszenie na Rzecz Mieszkańców Gminy D. do udziału w postępowaniu. Stowarzyszenie to poparło stanowisko skarżących, wskazując, że organ wydający decyzję zaniechał obowiązku informacyjnego, przez co lokalna społeczność została w sposób świadomy wprowadzona w błąd co do rzeczywistego posadowienia farmy wiatrowej i jej szkodliwego oddziaływania. W kolejnym piśmie procesowym Stowarzyszenie na Rzecz Mieszkańców Gminy D. dodatkowo podniosło niezgodność decyzji Wójta Gminy D. z ustaleniami miejscowego planu zagospodarowania przestrzennego.

Wojewódzki Sąd Administracyjny w Szczecinie w wyroku z dnia 18 kwietnia 2018 r. $^{3}$ oddalił skargę skarżących, gdyż nie dopatrzył się w zaskarżonej decyzji uchybień, które mogłyby skutkować jej uchyleniem, ponieważ zdaniem sądu pierwszej instancji Samorządowe Kolegium Odwoławcze dokonało właściwej oceny wniosku skarżących i zasadnie przyjęło, że podnoszone zarzuty nie mogły stanowić podstawy stwierdzenia nieważności decyzji Wójta Gminy D. Również zarzuty stawiane przez Stowarzyszenie na Rzecz Mieszkańców Gminy D. zdaniem sądu nie zasługują na uwzględnienie.

W tej sytuacji skarżący wnieśli do Naczelnego Sądu Administracyjnego skargę kasacyjną. W skardze podniesiono cały szereg zarzutów w stosunku do decyzji Wójta Gminy D. oraz następującej po niej decyzji Samorządowego Kolegium Odwoławczego i przywołanego przed chwilą wyroku Wojewódzkiego Sądu Administracyjnego w Szczecinie. Naczelny Sąd Administracyjny analizował wiele zarzutów podniesionych w skardze kasacyjnej. Zajął się m.in. zagadnieniem wariantowania analizowanego przedsięwzięcia, które budzi pewne wątpliwości.

\section{Sposoby wariantowania}

Ustawa z dnia 3 października 2008 r. o udostępnianiu informacji o środowisku i jego ochronie, udziale społeczeństwa w ochronie środowiska oraz o ocenach oddziaływania na środowisko w art. 66 ust. 1 pkt 5 definiuje, że raport o oddziałaniu przedsięwzięcia na środowisko powinien zawierać trzy warianty: wariant proponowany przez wnioskodawcę, racjonalny wariant alternatywny oraz racjonalny wariant najkorzystniejszy dla środowiska. Identyczne rodzaje wariantów wymienia

3 Wyrok WSA w Szczecinie z dnia 18 kwietnia 2018 r., II SA/Sz 536/15, LEX nr 2505711. 
również Krzysztof Gruszecki w swoim komentarzu do tej ustawy ${ }^{4}$, przy czym rozwija tę kwestię, stwierdzając, że wariant zaproponowany przez wnioskodawcę może być równocześnie wariantem najkorzystniejszym dla środowiska, co w praktyce doprowadzi do analizy tylko dwóch wariantów. Autor ten podkreśla jednak, że analizowane warianty nie mogą mieć charakteru pozornego, co miałoby miejsce, gdyby $\mathrm{w}$ tym samym miejscu i z technicznego punktu widzenia planowano warianty niewiele różniące się między sobą. Ustawa o udostępnianiu informacji o środowisku i jego ochronie, udziale społeczeństwa w ochronie środowiska oraz o ocenach oddziaływania na środowisko nie przewiduje żadnych innych dodatkowych wymagań w stosunku do analizowanych wariantów planowanego przedsięwzięcia.

Zagadnienia oceny oddziaływania na środowisko reguluje również dyrektywa Parlamentu Europejskiego i Rady 2011/92/UE w sprawie oceny skutków wywieranych przez niektóre przedsięwzięcia publiczne i prywatne na środowisko ${ }^{5}$, zmieniona dyrektywą Parlamentu Europejskiego i Rady 2014/52/UE6. Art. 4 ust. 3 określa, że podczas przeprowadzania badania indywidualnego lub ustalania progów powinny być spełnione kryteria selekcji określone w załączniku III do dyrektywy. Załącznik ten wśród cech przedsięwzięć wymienia po pierwsze rozmiar przedsięwzięcia, czyli jego skalę, wielkość produkcji czy moc zainstalowaną. Dyrektywa nakazuje również analizę rozwiązań alternatywnych, bez określania innych szczegółowych wymogów ich wyboru, za wyjątkiem podania głównych powodów wybrania tych wariantów wraz z podaniem ich skutków środowiskowych.

Marcin Pchałek i Michał Behnke $e^{7}$ zauważają, że w polskiej praktyce wariantowanie ograniczane jest głównie do możliwej zmiany przebiegu inwestycji liniowej. Wymieniają oni następujące możliwości prowadzenia analizy wariantowej:

- warianty związane z rodzajem przedsięwzięcia, w ramach których rozpatrzone winny być: stosowane procesy i technologie, metody prowadzenia działalności, czas prowadzenia działalności, konstrukcja obiektów, program realizacji przedsięwzięcia, skala przedsięwzięcia, systemy zarządzania, procedury w zakresie zarządzania środowiskowego, rozwiązania w zakresie zatrudniania i szkolenia

4 K. Gruszecki, Ustawa o udostępnianiu informacji o środowisku i jego ochronie, udziale społeczeństwa w ochronie środowiska oraz o ocenach oddziaływania na środowisko. Komentarz, Warszawa 2009, s. 181.

5 Dyrektywa Parlamentu Europejskiego i Rady 2011/92/UE z dnia 13 grudnia 2011 r. w sprawie oceny skutków wywieranych przez niektóre przedsięwzięcia publiczne i prywatne na środowisko, Dz. Urz. UE L 26/1 z 28.01.2012, s. 1.

6 Dyrektywa Parlamentu Europejskiego i Rady 2014/52/UE z dnia 16 kwietnia 2014 r. zmieniająca dyrektywę 2011/92/UE w sprawie oceny wpływu wywieranego przez niektóre przedsięwzięcia publiczne i prywatne na środowisko, Dz. Urz. UE L 124/1 z 25.04.2014, s. 1.

$7 \quad$ M. Pchałek, M. Behnke, Postępowanie w sprawie oceny oddzialywania na środowisko w prawie polskim i UE, Warszawa 2009, s. 113. 
pracowników, rozwiązania w zakresie likwidacji przedsięwzięcia, rekultywacji i planowanego późniejszego wykorzystania terenu;

- warianty związane z lokalizacją przedsięwzięcia, obejmujące umiejscowienie przedsięwzięcia, trasy dojazdowe, zagospodarowanie działki i usytuowanie obiektów, rozwiązania w zakresie dojazdu, obiekty pomocnicze;

- warianty związane $\mathrm{z}$ oddziaływaniem przedsięwzięcia na środowisko, według kryteriów, takich jak: metody ograniczania emisji, metody gospodarowania odpadami, monitoring i instrukcje postępowania na wypadek awarii;

- warianty ze względu na inne zagadnienia, obejmujące: politykę w zakresie racjonalnego wykorzystania zasobów środowiska, politykę w zakresie wytwarzania produktów przyjaznych środowisku.

Elżbieta Szafranko ${ }^{8}$ rozróżnia natomiast następujące możliwości wariantowania, związane z:

- rodzajem przedsięwzięcia i obejmujące stosowane procesy i technologie, czas i metody prowadzenia robót, konstrukcje obiektów, źródła i rodzaje wykorzystywanych surowców, program realizacji przedsięwzięcia, systemy zarządzania;

- lokalizacją przedsięwzięcia, uwzględniającą przebieg drogi, zagospodarowania działki, umiejscowienia obiektów towarzyszących, rozmieszczenia tras dojazdowych, rozwiązania dotyczące dojazdu i dostaw wymagających materiałów budowlanych;

- oddziaływaniem przedsięwzięcia na środowisko, obejmującym metody ograniczania emisji szkodliwych substancji, kontrolę, monitoring i instrukcje postępowania na wypadek awarii lub katastrofy;

- innymi czynnikami, takimi jak: harmonogram realizacji przedsięwzięcia, polityka w zakresie wytwarzania produktów przyjaznych środowisku i racjonalnego wykorzystania zasobów środowiska oraz inne, zależne od sytuacji.

W podręczniku dobrych praktyk wykonywania opracowań środowiskowych dla dróg krajowych ${ }^{9}$ zaleca się prowadzenie wariantowania zależnego od możliwości terenowych, technicznych i ekonomicznych, które mogą być podzielone na warianty: lokalizacyjne, techniczne i technologiczne, organizacyjne, urządzeń ochrony środowiska oraz kompensacji przyrodniczej. Wśród analizowanych wariantów możliwe są różne parametry techniczne (wykopy, nasypy, rozwiązania węzłów drogowych, rodzaj obiektów drogowych czy stosowanej nawierzchni).

8 E. Szafranko, Metody analizy wariantów inwestycji drogowych, Drogownictwo 2014, nr 1, s. 18-25.

$9 \quad$ Podręcznik dobrych praktyk wykonywania opracowań środowiskowych dla dróg krajowych, red. J. Bohatkiewicz, Kraków 2008, s. 116, http://siskom.waw.pl/nauka/literatura/podreczNik_dobrych_praktyk.pdf [dostęp: 26.04.2020 r.]. 
Według Grzegorza Klimka ${ }^{10}$ wariantowanie powinno określać takie elementy przedsięwzięcia, jak: rodzaj przedsięwzięcia (np. w zakresie stosowanych technologii, sposobów projektowania poszczególnych obiektów instalacji, rodzajów substancji wykorzystywanych w procesach technologicznych, programu realizacji przedsięwzięcia), lokalizację przedsięwzięcia, charakter oddziaływania na środowisko czy politykę racjonalnego wykorzystania środowiska. Dodatkowo wariantowanie może dotyczyć również sposobu zagospodarowania terenu, rozwiązań w zakresie obiektów zewnętrznych, sieci transportu, zasilania, organizacji robót, doboru materiałów, czasu realizacji inwestycji. Jacek Krystek ${ }^{11} \mathrm{z}$ kolei wyróżnił wariantowanie, które może dotyczyć np.: lokalizacji przedsięwzięcia, zagospodarowania terenu przedsięwzięcia (tras dojazdowych, lokalizacji instalacji i obiektów pomocniczych), rodzaju technologii, skali inwestycji, harmonogramu działania inwestycji, rozwiązań technicznych, rozwiązań chroniących środowisko, sposobu organizacji pracy, sposobów działań kompensacyjnych.

Opinia na temat wariantów planowanego przedsięwzięcia podczas prowadzonego postępowania w sprawie oceny oddziaływania na środowisko została również wydana $\mathrm{w}$ innym postępowaniu prowadzonym przed sądem administracyjnym. Naczelny Sąd Administracyjny ${ }^{12}$ określił, jakie jego zdaniem warunki powinny spełniać analizowane warianty przedsięwzięcia i stwierdzil, że warianty przedsięwzięcia, o których mowa w art. 66 ust. 1 pkt 5 ustawy z dnia 3 października 2008 r., powinny się różnić przede wszystkim pod względem sposobu, w jaki przedsięwzięcie w każdym z tych wariantów będzie oddziaływać na środowisko, ponieważ ich rolą jest wskazanie alternatywnych rozwiązań pozwalających to środowisko chronić w jak najpełniejszym wymiarze. Ponadto warianty przedsięwzięcia nie mogą odbiegać od siebie w takim stopniu, który oznaczałby swoistą zmianę tożsamości tego przedsięwzięcia poprzez przekształcenie jego konstytutywnych, fundamentalnych parametrów i prowadziłby w rezultacie do zaproponowania do realizacji kilku różnych przedsięwzięć tego samego rodzaju. Powinny one poprzestać na korekcie parametrów dokonywanych w ramach jednego przedsięwzięcia.

10 G. Klimek, Raport o oddziaływaniu przedsięwzięcia na środowisko w świetle przepisów prawa polskiego, w: Ocena oddziaływania na środowisko w praktyce, red. B. Rakoczy, Warszawa 2017, s. 74-75.

11 J. Krystek, Ocena oddziaływania na środowisko, w: Ochrona środowiska dla inżynierów, red. J. Krystek, Warszawa 2018, s. 534; tenże, Ocena oddziaływania na środowisko. Teoria i praktyka, Warszawa 2020, s. 224 .

12 Wyrok NSA z dnia 29 stycznia 2015 r., II OSK 1605/13, LEX nr 1769926. 


\section{Ocena rozstrzygnięcia}

W analizowanym wyroku z dnia 23 stycznia 2019 r., II OSK 3147/18, Naczelny Sąd Administracyjny uznał, że dwa warianty technologiczne farmy wiatrowej, polegające na zróżnicowaniu ich mocy (wariant I o mocy 22,5 MW oraz wariant II o mocy $18 \mathrm{MW)} \mathrm{w} \mathrm{rzeczywistości} \mathrm{opisują} \mathrm{nie} \mathrm{jedno,} \mathrm{lecz} \mathrm{dwa} \mathrm{przedsięwzięcia,}$ przez co doszło do fikcyjnego, a nie rzeczywistego wariantowania przedsięwzięcia. Sąd uznał tym samym, że racjonalne warianty technologiczne, które przedstawiono w raporcie oceny oddziaływania, nie spełniają warunków racjonalnego wariantu alternatywnego. Dalej sąd stwierdził, że łączna moc zespołu turbin wiatrowych w każdym wariancie realizacji przedsięwzięcia opisanym w raporcie powinna być taka sama. W przeciwnym razie raport przedstawia opis nie jednego, lecz kilku przedsięwzięć.

Analizując literalne brzmienie przepisu art. 66 ust. 1 pkt 5 ustawy o udostępnianiu informacji o środowisku i jego ochronie, udziale społeczeństwa w ochronie środowiska oraz o ocenach oddziaływania na środowisko należy stwierdzić, że nie wprowadza on żadnych ograniczeń w stosunku do wymogów w odniesieniu do warunków, jakie muszą spełniać warianty analizowanego przedsięwzięcia poddawanego ocenie oddziaływania na środowisko. Ustawa wymaga, żeby opisać, z uwzględnieniem szczególnych cech przedsięwzięcia lub jego oddziaływania, co najmniej: wariant proponowany przez wnioskodawcę, racjonalny wariant alternatywny oraz racjonalny wariant najkorzystniejszy dla środowiska. Dodatkowo w art. 66 ust. 1 pkt $6 a$ ustawy z dnia 3 października 2008 r. ustawodawca zalecił przeprowadzenie $\mathrm{w}$ raporcie oddziaływania na środowisko porównania oddziaływań analizowanych wariantów. Wynika z tego, że warianty te musiały się różnić jakimiś elementami, bo inaczej oddziaływania byłyby identyczne. Z literalnego brzmienia przepisów rzeczonej ustawy nie można więc wysnuć wniosku, że jakieś warianty są niedozwolone, jeżeli tylko są racjonalnym wariantem alternatywnym i właśnie alternatywność jest jedynym kryterium, pod względem którego możemy oceniać dopuszczalność przyjęcia danego wariantu do analizy.

Kolejną metodą oceny analizowanego zagadnienia jest metoda celowościowa. Ustawa o udostępnianiu informacji o środowisku i jego ochronie, udziale społeczeństwa $\mathrm{w}$ ochronie środowiska oraz o ocenach oddziaływania na środowisko ma realizować dwie zasady zdefiniowane w ustawie Prawo ochrony środowiska ${ }^{13}$, tzn. zasadę prewencji i zasadę przezorności. Stanowią one, że kto podejmuje

13 Ustawa z dnia 27 kwietnia 2001 r. - Prawo ochrony środowiska, tekst jednolity: Dz. U. z 2020 r. poz. $1219 \mathrm{z}$ późn. zm. 
działalność mogącą negatywnie oddziaływać na środowisko, jest obowiązany do zapobiegania temu oddziaływaniu, oraz że kto podejmuje działalność, której negatywne oddziaływanie na środowisko nie jest jeszcze w pełni rozpoznane, jest zobowiązany, kierując się przezornością, podjąć wszelkie możliwe środki zapobiegawcze. Ocena oddziaływania na środowisko ma po pierwsze doprowadzić do zidentyfikowania możliwych niekorzystnych wpływów planowanego przedsięwzięcia. Po drugie pozwala ona dokonać wyboru najmniej szkodliwego dla środowiska wariantu. Podkreśla to szczególnie art. 81 ust. 1 ustawy z dnia 3 października 2008 r., zgodnie z którym organ wydający decyzję o środowiskowych uwarunkowaniach może ją wydać tylko dla wariantu najkorzystniejszego dla środowiska. Czy zmiana skali przedsięwzięcia w stosunkowo niewielkim zakresie jest w stanie zmienić celowość omawianych przepisów? Zapewne nie. Na pewno zmiana skali wpłynie na wielkość oddziaływań, a tym samym na zróżnicowanie wariantów. Czy zatem zmiana skali przedsięwzięcia zmieni rodzaj przedsięwzięcia? Logika wskazuje, że odpowiedź musi być negatywna.

Na koniec do oceny analizowanego przypadku zastosujmy metodę analizy i krytyki piśmiennictwa. Przytoczone wcześniej źródła, odnoszące się do sposobów analizy wariantowej poddawanego ocenie oddziaływania na środowisko przedsięwzięcia, wymieniały rozmaite sposoby różnicowania wariantów poddawanych ocenie. Niektórzy autorzy wprost stwierdzali, że jednym z możliwych sposobów różnicowania wariantów może być ich skala. W żadnym opracowaniu nie wprowadzono jednak jakichś ograniczeń, którym może podlegać sposób wariantowania.

Nie można się więc zgodzić z poglądem przedstawionym przez Naczelny Sąd Administracyjny w omawianym orzeczeniu. Dlaczego zmiana lokalizacji przedsięwzięcia (np. zmiana przebiegu drogi) jest powszechnie akceptowana w orzecznictwie, a zmiana skali inwestycji nie? Przecież zmiana skali musi zostać dokonana albo poprzez zmianę rodzaju turbin wiatrowych, albo poprzez zmianę ich lokalizacji. Tym samym zmiany te spowodują zmianę sposobu oddziaływania na środowisko. Należy dodatkowo podkreślić, że wielkość mocy turbin wiatrowych w omawianym przypadku wynosiła $22,5 \mathrm{MW}$ oraz $18 \mathrm{MW}$, a zatem różnica między nimi to tylko $20 \%$ lub 25\% (w zależności od sposobu liczenia). Nawet gdyby różnica wynosiła wielokrotnie więcej, to zmiana skali przedsięwzięcia nie zmieniałaby jego rodzaju. Spowodowałaby jednak, że nie byłby spełniony warunek alternatywności wariantu.

Raport oceny oddziaływania powinien zawierać elementy wymienione w art. 66, przy uwzględnieniu kryteriów zapisanych w art. 62 ustawy o udostępnianiu informacji o środowisku i jego ochronie, udziale społeczeństwa w ochronie środowiska oraz o ocenach oddziaływania na środowisko. Przyjęcie, że zmiana skali planowanego 
przedsięwzięcia nie jest wariantowaniem określonym w art. 66 ust. 1 pkt 5, nie znajduje uzasadnienia w brzmieniu tego przepisu. Normuje on, że warianty mają uwzględniać „szczególne cechy przedsięwzięcia lub jego oddziaływania”. Zmiana skali przedsięwzięcia ewidentnie powoduje, że dane przedsięwzięcie zmienia swoje cechy, a tym samym oddziaływanie na środowisko. Przez zmianę mocy farmy wiatrowej nie zmienia się przecież jej charakter. Czy przez zmianę przebiegu planowanej drogi zmienia się ona w inne przedsięwzięcie?

Ustawodawca rozumiejąc znaczenie właściwej kwalifikacji przedsięwzięcia, wprowadził upoważnienie ustawowe dla Rady Ministrów do określenia, w drodze rozporządzenia, rodzaju przedsięwzięć mogących zawsze znacząco lub potencjalnie znacząco oddziaływać na środowisko. Obecnie wymóg ten spełnia rozporządzenie Rady Ministrów z dnia 10 września 2019 r. w sprawie przedsięwzięć mogących znacząco oddziaływać na środowisko ${ }^{14}$. Kryteriami powodującymi zaliczenie danego przedsięwzięcia do odpowiedniej grupy jest rodzaj oraz skala działalności. Tym samym zmiana skali przedsięwzięcia nie powinna powodować uznania, że nie traktuje się go jako wariant, tylko jako inne przedsięwzięcie. Należy mieć na uwadze, że w pewnych sytuacjach zmiana skali przedsięwzięcia jest jedynym, technicznie możliwym, sposobem wariantowania, które jest obowiązkowo wymagane przez ustawę o udostępnianiu informacji o środowisku i jego ochronie, udziale społeczeństwa w ochronie środowiska oraz o ocenach oddziaływania na środowisko. Z tego względu wniosków wyciągniętych w glosowanym wyroku Naczelnego Sądu Administracyjnego w zakresie wymogów, jakie muszą spełniać warianty analizowanego przedsięwzięcia, nie można uznać za poprawne. Ustawa z dnia 3 października 2008 r. nie wprowadza żadnych wymogów formalnych, jakie w czasie oceny oddziaływania na środowisko muszą spełniać analizowane warianty, za wyjątkiem alternatywności w stosunku do wariantu proponowanego przez wnioskodawcę.

\section{Bibliografia}

Gruszecki K., Ustawa o udostępnianiu informacji o środowisku i jego ochronie, udziale społeczeństwa w ochronie środowiska oraz o ocenach oddziaływania na środowisko. Komentarz, Warszawa 2009.

Klimek G., Raport o oddziaływaniu przedsięwzięcia na środowisko w świetle przepisów prawa polskiego, w: Ocena oddziaływania na środowisko w praktyce, red. B. Rakoczy, Warszawa 2017.

14 Dz. U. z 2019 r. poz. 1839. 
Krystek J., Ocena oddziaływania na środowisko. Teoria i praktyka, Warszawa 2020.

Krystek J., Ocena oddziaływania na środowisko, w: Ochrona środowiska dla inżynierów, red. J. Krystek, Warszawa 2018.

Pchałek M., Behnke M., Postępowanie w sprawie oceny oddziaływania na środowisko w prawie polskim i UE, Warszawa 2009.

Podręcznik dobrych praktyk wykonywania opracowań środowiskowych dla dróg krajowych, red. J. Bohatkiewicz, Kraków 2008, http://siskom.waw.pl/nauka/literatura/podrecznik dobrych_praktyk.pdf [dostęp: 26.04.2020 r.].

Szafranko E., Metody analizy wariantów inwestycji drogowych, Drogownictwo 2014, nr 1. 